\title{
Analysis of Technology Acceptance Model (TAM) on E-Learning System
}

\author{
${ }^{1}$ Darmawan Napitupulu \\ ${ }^{1}$ Research Center for Quality System and Testing Technology, Indonesian Institute of Sciences, Tangerang Selatan, Indonesia \\ darmawan.baginda.napitupulu@lipi.go.id \\ ${ }^{2}$ Janner Simarmata \\ ${ }^{2}$ State University of Medan, Indonesia \\ jannersimarmata@unimed.ac.id \\ ${ }^{3}$ Leon Andretti Abdillah \\ ${ }^{3}$ Departement of Information Systems, Universitas Bina Darma, Palembang, Indonesia \\ leon.abdillah@yahoo.com \\ ${ }^{4}$ Muhammad Ikhsan Setiawan \\ ${ }^{4}$ Narotama University, Indonesia \\ ikhsan.setiawan@narotama.ac.id \\ ${ }^{5}$ Ansari Saleh Ahmar \\ ${ }^{5}$ Departement of Statistics, Universitas Negeri Makassar, Indonesia \\ ansarisaleh@unm.ac.id \\ ${ }^{6}$ Robbi Rahim \\ ${ }^{6}$ School of Computer and Communication Engineering, Universiti Malaysia Perlis, Malaysia \\ usurobbi85@zoho.com \\ ${ }^{7}$ Heri Nurdiyanto \\ ${ }^{7}$ Informatics Engineering Departement, STMIK Dharma Wacana Lampung, Indonesia \\ herinurdiyanto@gmail.com \\ ${ }^{8}$ Wahyuddin Albra, ${ }^{9}$ Dahlan Abdullah, ${ }^{11}$ Cut Ita Erliana \\ ${ }^{8}$ Departement of Accounting, Universitas Malikussaleh Aceh, Indonesia \\ ${ }^{9}$ Department of Informatics, Universitas Malikussaleh Aceh, Indonesia \\ ${ }^{11}$ Departement of Industrial, Universitas Malikussaleh, Aceh, Indonesia \\ wahyudin@unimal.ac.id, dahlan@unimal.ac.id, cutitha@unimal.ac.id \\ ${ }^{10}$ Rahmat Hidayat \\ ${ }^{10}$ Department of Information Technology, Politeknik Negeri Padang, Indonesia \\ rahmat@polinpdg.ac.id
}

\footnotetext{
Abstract-Advances in science and technology, especially Information and Communication Technology (ICT) more positive impact for the advancement of education today. Various advantages of e-learning to encourage the use of e-learning has become a necessity these days is no longer a necessity or
}

compulsion. Utilization of e-learning in the learning process was already inevitable. This study aims to find a picture of the successful implementation of e-learning based on user acceptance within the University XYZ.. User acceptance can predict the level of utilization of the technology in the future. The method used in 
this study is a survey with TAM approach that statistically analyzed descriptively. The total number of respondents was 73 people chosen by purposive sampling. The results show the user agrees to the usefulness of e-learning system with a percentage of $69.12 \%$, users also agree with the ease of use of e-learning with a percentage of $69.80 \%$ and the overall user agrees with the acceptance of e-learning system with a percentage of $72.69 \%$.

Keywords-e-learning; TAM; user acceptance; ease of use; usefulness

\section{INTRODUCTION}

Advances in science and technology, especially Information and Communication Technology (ICT) have a lot of positive impacts for the advancement of education today. Formal education, informal, and non-formal can utilize ICT to support the learning process to the learners. Excellence offered not only lies in the speed factor and ease in obtaining information or material resources, but also the multimedia facilities that can make the learning process more interesting through the interactive visual. The advantages of e-learning encourage the use of e-learning today has become a necessity no longer necessity or compulsion. Utilization of e-learning system in the learning process was already inevitable. The advantages offered by e-learning are more flexible learning opportunities without space and time, making it easier for people to access education, enriching learning materials, enabling learning processes, making learning more open, improving the effectiveness of learning, and supporting learners to learn independent [21]

Even the development of education towards e-learning is needed in order to improve the quality standard of education because e-learning is the use of internet technology in the delivery of learning based on three criteria, namely: (1) elearning is a network with the ability to update, store, distribute and share teaching materials or information, (2) deliveries that are up to the last user via computer using standard internet technologies; (3) focusing on a broader view of learning behind the traditional learning paradigm (Rosenberg, 2001). But the term e-learning is actually not just limited to the internet alone, it refers to the definition of e-learning based on Glossary of elearning Term which states that e-learning is an educational system that uses electronic applications to support the process of teaching and learning with internet media, computer network and standalone computers [8]. But it is undeniable that internet-based learning is one of the most popular e-learning manifestations today.

In the previous study [2], XYZ university readiness level study on the implementation of e-Learning system has been done using ELR (E-Learning Readiness) model. Based on 10 ELR factors identified, there are 5 ELR factors are not ready, i.e. HR, financial, infrastructure, innovation and institution. In fact, it can be said that XYZ University is in the category of not ready needs some works. Based on the existing condition of readiness, the question arises whether e-learning applied will succeed or otherwise fail? To answer that question, research needs to be done to know how the user acceptance of technology or e-learning system? By knowing the level of user acceptance of a technology, can be predicted utilization rate. If the level of user acceptance is high then it can be assured the level of utilization of technology will be high also and if referring theory of Delone \& McLean (2003) hence can be say successful e-learning implementation.

Therefore, in this study, user acceptance measurement of the e-learning system is implemented. Thus, expected to obtain a picture of the success of e-learning system based on perspectives of users in the university XYZ.

\section{LITERATUR REVIEW}

The technology acceptance model (TAM) is a model that has been used extensively in various domains such as business, government to education that utilize information technology in its business processes. In the field of education, there are already a number of researchers who use TAM to explain user acceptance of technologies such as e-learning, multimedia learning technologies, digital libraries, e-journals, etc.

In the context of e-learning, research conducted by [18] on a number of university students in Korea related interest in using e-learning. The results of his research share that TAM is a suitable theory to understand the acceptance of e-learning users. The two variables i.e. ease of use and usefulness have a significant effect on behavioral intention to use e-learning. The TAM model is also used by [3] who conducted case study research at Applied Science University (ASU) in Amman. The results show that TAM can be applied as a useful theory to predict user acceptance of e-learning. In addition, there are other studies that use TAM in the context of e-learning [2,3,5].

In addition to e-learning, TAM utilization is also applied to the development of multimedia learning technologies such as those conducted by [23]. The researcher have conducted a study of user acceptance of Google technology (Google Clasroom) on STT Musi Palembang. In the context of digital libraries and e-journals, some researchers have also used the TAM model to examine factors affecting user acceptance of digital libraries [13, 22]. According to Thong (2004), one's acceptance of digital library technology influences its utilization rate in the future. Based on TAM theory, the rate of technology utilization will be greatly determined by the level of user acceptance. In other words, user acceptance will predict the utilization rate. If the level of user acceptance is high then it can be assured that the utilization rate of the technology will be high, and if it refers to Delone \& McLean theory (2003) then the implementation of technology can be said successful [6].

\section{RESEARCH METHODOLOGY}

Technology Acceptance Model (TAM) is an approach used to measure the extent to which the level of user acceptance of e-learning technology. The survey was conducted to a number of respondents with a total of 85 people who asked their level of approval of each variable in TAM. Selection of respondents conducted by purposive sampling i.e. students with criteria have been using e-learning system at XYZ university. The TAM model as mentioned earlier has five variables: perceived ease of use, perception of benefits, attitude to use, interest in use behavior and actual system use [7,13,15]. In its 
development, the TAM model undergoes various modifications. [9] have developed the TAM model by combining the behavior interest variable with the actual use of the system into the acceptance variable. Therefore, in this research TAM model that will be used is to follow Gahtani (2001) consisting of three variables namely perceived usefulness, perceived ease of use and acceptance as in Table I.

TABLE I. RESEARCH OPERATIONAL ITEM

\begin{tabular}{|c|c|c|}
\hline No & Item & Indicator \\
\hline \multirow[t]{6}{*}{1.} & \multirow[t]{6}{*}{ Perceived Usefulness (X1) } & Accelerate work (X1.1) \\
\hline & & Improved performance (X1.2) \\
\hline & & Increase productivity (X1.3) \\
\hline & & Effectiveness (X1.4) \\
\hline & & Simplify work (X1.5) \\
\hline & & Helpful (X1.6) \\
\hline \multirow[t]{6}{*}{2.} & \multirow[t]{6}{*}{ Perceived Ease of Use (X2) } & Easy to learn (X2.1) \\
\hline & & Can be controlled (X2.2) \\
\hline & & Clear and understandable (X2.3) \\
\hline & & Flexible (X2.4) \\
\hline & & Easy to be skilled (X2.5) \\
\hline & & Easy to use (X2.6) \\
\hline \multirow[t]{4}{*}{3.} & \multirow[t]{4}{*}{ Acceptance (Y) } & Real Use (Y.1) \\
\hline & & Frequency of Use (Y.2) \\
\hline & & User Satisfaction (Y.3) \\
\hline & & Recommend other users (Y.4) \\
\hline
\end{tabular}

The instrument of the research questionnaire is designed with a Likert scale consisting of 4 scales i.e. 1 = "strongly disagree", 2 = "disagree", 3 = "agree" and 4 = "strongly agree" (Likert scale), Table II.

Data analysis techniques used in this research is descriptive statistical analysis techniques with the steps performed as follows.

1. Determining the magnitude of the criterion score in accordance with the results obtained from the previous data processing. The criterion score (SK) is the ideal score achieved in a study. If it is assumed that all respondents (numbered 100) assigned choose the answer the lowest number is 1 for 1 question, then the lowest score is 100. If assumed all respondents are chosen to choose the highest number of 5 for 1 question, then the highest score is 500. Highest score this is called the criterion score. How to get this criterion score is to use the following formula:

\section{$\Sigma \mathrm{SK}=$ Highest score for each item of question $\mathrm{x}$ number of} question items $\mathrm{x}$ number of respondents

2. Then, determined the total score of the data collection that has been done. The total score of data collected is symbolized by $\Sigma \mathrm{SH}$.

3. After the criterion score $(\Sigma \mathrm{SK})$ and the total score of data collected $(\Sigma \mathrm{SH})$ is obtained, then the percentage $(\mathrm{P})$ of the respondent's answer is searched using the following formula:

$$
\mathrm{P}=\Sigma \mathrm{SH} / \Sigma \mathrm{SK} \times 100 \%
$$

Where, $\mathrm{P}$ is percentage of respondents' answers; $\Sigma \mathrm{SK}$ is criteria score; $\Sigma \mathrm{SH}$ is the total score of data collected

4. The final step is to determine the range of results based on the criterion score and the percentage obtained for later compared with the score of data collection results. The range of results can be presented in Table III.

TABLE II. CATEGORY OF RESPONDENT RESPONSE

\begin{tabular}{|l|l|}
\hline Percentage $(\mathrm{P})$ & Category of Response \\
\hline $0-25 \%$ & Strongly Disagree \\
\hline $26-50 \%$ & Disagree \\
\hline $51-75 \%$ & Agree \\
\hline $76-100 \%$ & Strongly Agree \\
\hline
\end{tabular}

\section{RESULT AND DISCUSSIONS}

\section{A. Validity dan Reliability of Instrument}

Based on the results of data collection, from 85 questionnaires data there are only 73 data that can be continued in the stage of processing and data analysis. In other words, there are 12 data questionnaires that are not included in the next stage due to incomplete data filling by respondents. But before the questionnaire data is analyzed further, the instrument will be tested for its validity and reliability to ensure that the instruments used are accurate and reliable. To prove it, the results of validity test in this study refers to the magnitude of the validity index is the value of $r_{\text {count }}$ (corrected item-total correlation). According to $[4,12]$, an item in the instrument is said to be valid if the value of $r_{\text {count }}$ is greater than the $r_{\text {table }}$ where $r_{\text {table }}$ for 73 respondents is 0.2303 .

TABLE III. VALIDITY OF INSTRUMENT

\begin{tabular}{|l|l|l|l|}
\hline No & Indicator & $\begin{array}{l}\text { Corrected Item-Total } \\
\left.\text { Correlation ( } \mathrm{r}_{\text {hasil }}\right)\end{array}$ & \\
\hline Perceived Usefulness (X1) & 0.649 & VALID \\
\hline 1. & Accelerate work (X1.1) & 0.670 & VALID \\
\hline 2. & Improved performance (X1.2) & VALID \\
\hline 3. & Increase productivity (X1.3) & 0.583 & VALID \\
\hline 4. & Effectiveness (X1.4) & 0.432 & VALID \\
\hline 5. & Simplify work (X1.5) & 0.618 & VALID \\
\hline 6. & Helpful (X1.6) & 0.531 & VALID \\
\hline Perceived Ease of Use (X2) & 0.663 & VALID \\
\hline 1. & Easy to learn (X2.1) & 0.590 & VALID \\
\hline 2. & Can be controlled (X2.2) & VALID \\
\hline 3. & Clear and understandable (X2.3) & 0.603 & VALID \\
\hline 4. & Flexible (X2.4) & 0.649 & VALID \\
\hline 5. & Easy to be skilled (X2.5) & 0.610 & \\
\hline 6. & Easy to use (X2.6) & 0.686 & VALID \\
\hline Acceptance (Y) & 0.549 & VALID \\
\hline 1. & Real Use (Y.1) & 0.583 & VALID \\
\hline 2. & Frequency of Use (Y.2) & 0.721 & VALID \\
\hline 3. & User Satisfaction (Y.3) & 0.654 & \\
\hline 4. & Recommend other users (Y.4)
\end{tabular}

Based on Table III it can be seen that each item (statement) has a value of $r_{\text {count }}$ greater than $r_{\text {table }}(0.2303)$. Thus the entire item can be said to be valid because it has met the requirements $(>0.2303)$.

Reliability testing questionnaire in this study was conducted with Cronbach alpha. According [12], Cronbach alpha technique is a technique that will show the index of internal consistency that is accurate, fast, and economical. The instrument is said to meet reliability if the value of Cronbach alpha is greater than 0.60 . Reliability test results of the questionnaire can be presented in Table IV. 
TABLE IV. RELIABILITY OF INSTRUMENT

\begin{tabular}{|l|l|l|}
\hline No & Item/Variable & Cronbach Alpha \\
\hline 1. & Perceived ease of use & 0.793 \\
\hline 2. & Perceived usefulness & 0.823 \\
\hline 3. & Acceptance & 0.828 \\
\hline
\end{tabular}

Based on Table IV it can be shown that each TAM variable is perception of usability, perception of ease of use and acceptance is said to be reliable. This is evidenced by the value of Cronbach alpha as an acceptance variable reliability index of 0.828 , perceived usefulness of 0.823 and perceived ease of use of 0.793 . Overall, the reliability index obtained is 0.916 . The results of Cronbach alpha is greater than 0.60 as a condition that the instrument can be said reliable. Thus the instrument in this study is valid and reliable because it meets the requirements.

\section{B. Statistical Descriptive}

In this section we will present descriptive statistical analysis which is done to know the questionnaire result of each variable included in the category of answer Strongly Disagree, Disagree, Agree and Strongly Agree which can be seen as follows:

\section{1) Perceived Usefulness}

- Determine the magnitude of the criterion score (SK) obtained:

$\Sigma \mathrm{SK}=$ Highest score for each item of question $\mathrm{x}$ number of question items $\mathrm{x}$ number of respondents

Highest score item question $=4$

Number of question items $=6$

Number of respondents $=73$

$$
\Sigma \mathrm{SK}=4 \times 6 \times 73=1752
$$

- Total number of total results of data collection of variable usability (X1):

$$
\Sigma \mathrm{SH}=1211
$$

- The percentage $(\mathrm{P})$ of respondents' answers:

$$
\mathrm{P}=\Sigma \mathrm{SH} / \Sigma \mathrm{SK}=1211 / 1752 \times 100 \%=69.12 \%
$$

Based on the percentage value $(\mathrm{P})$ and refer to Table IV above the category of respondents' answers can be seen that the results of the percentage distribution of respondents overall answer for the variable utilization (X1) included in the category "Agree" with percentage 69.12\%. The implication in this research is that the user assumes that e-learning system implemented is very useful in supporting and improving teaching and learning process. This encourages user acceptance of the implementation of e-learning within the university environment of XYZ [7,11].

\section{Perceived Ease of Use}

- Determine the magnitude of the criterion score (SK) obtained:

$\Sigma \mathrm{SK}=$ Highest score for each item of question $\mathrm{x}$ number of question items $\mathrm{x}$ number of respondents
The highest score of each question item $=4$

Number of question items $=6$

Number of respondents $=73$

$\Sigma \mathrm{SK}=4 \times 6 \times 73=1752$

- Total number of total results of data collection of variable usability (X1):

$$
\Sigma \mathrm{SH}=1223
$$

- The percentage $(\mathrm{P})$ of respondents' answers:

$$
\mathrm{P}=\Sigma \mathrm{SH} / \Sigma \mathrm{SK}=1223 / 1752=69.80 \%
$$

Based on the range of categories referring to Table IV above, it can be seen that the results of the percentage distribution of respondents' overall answers for the ease of use variable (X2) are included in the "Agree" category with the percentage of $69.80 \%$. The implication in this study is that users assess e-learning systems that are implemented easy to use and operate. This encourages user acceptance of the implementation of e-learning within the university environment of XYZ [7].

\section{Acceptance}

- Determine the magnitude of the criterion score (SK) obtained:

$\Sigma \mathrm{SK}=$ Highest score for each item of question $\mathrm{x}$ number of question items $\mathrm{x}$ number of respondents

The highest score of each question item $=4$

Number of question items $=4$

Number of respondents $=73$

$\Sigma \mathrm{SK}=4 \times 4 \times 73=1168$

- Total number of total results of data collection of variable usability (X1):

$$
\Sigma \mathrm{SH}=849
$$

- The percentage $(\mathrm{P})$ of respondents' answers:

$$
\mathrm{P}=\Sigma \mathrm{SH} / \Sigma \mathrm{SK}=849 / 1168=72.69 \%
$$

Based on the range of categories referring to Table IV, it can be seen that the results of the percentage distribution of respondents' overall answers for the acceptance variable (Y) are included in the "Agree" category with the percentage of $72.69 \%$. The implication in this research is that based on user perception, e-learning system implemented is quite high acceptance level. This is obtained because perceived ease of use and perceived usefulness have been assessed or deemed adequate beforehand by the user. The results of this study are in line with other studies where TAM can be used to predict user acceptance of technology $[1,6,13]$.

\section{CONCLUSION}

Based on the research that has been done can be drawn some conclusions as follows, (1) Perceived ease of use overall, $69.80 \%$ of users agree with ease of use of e-learning system in 
XYZ university environment, (2) Perceived usefulness as a whole, $69.12 \%$ of users agree with the benefits of e-learning system in XYZ university environment, (3) User acceptance as a whole, $72.69 \%$ of users agree with acceptance of e-learning system in XYZ university environment, (4) The results of the analysis indicate that the user in this case the student judge that e-learning system implemented is very useful and easy to use so as to increase acceptance to use the application. Thus if the level of user acceptance is high then it can be expected the level of technology utilization will be high also in the future, and (5) Further research suggestions can be studied descriptively by other variables of TAM model and analyzed in more depth to see how big influence of TAM independent variable to user acceptance.

\section{REFERENCES}

[1] Alharbi, S., \& Drew, S. 2014. Using the Technology Acceptance Model in Understanding Academics' Behavioural Intention to Use Learning Management Systems. International Journal of Advanced Computer Science and Applications, 5(1), pp: 143-155.

[2] Al-Busaidi, K., \& Al-Shihi, H. 2010. Instructors Acceptance of Learning Management Systems: A Theoretical Framework. Communications of the IBIMA.

[3] Azwar, S. 2012. Reliabilitas and Validity. Yogyakarta: Pustaka Pelajar.

[4] Dalimunthe, N., \& Wibisono, H. 2013. Jurnal Sains, Teknologi dan Industri. 11(1).

[5] Dasgupta, Subhasih, Mary, G., \& Nina, M. 2002. User Acceptance of ECollaboration Technology: An Extension of the Technology Acceptance Model. Group Decision and Negotiation, 11(2), pp: 87-100.

[6] Davis, F. D. 1989. Perceived Usefulness, Perceived Ease of Use, and User Acceptance of Information Technology. MIS Quarterly, 13(3), pp: 319-339.
[7] Farhad, S. 2001, "Distance Education : An Introduction". Saba \& Associates. Sumber : http://www.distance-educator.com/portals/research_deintro.html

[8] Gahtani, S.A. 2001. The Applicability of TAM Outside North America: An Empirical Test in United Kingdom. Information Resource Management Journal, pp: 37-46.

[9] Kim, D., \& Chang, H. 2007. Key functional characteristics in designing and operating health information websites for user satisfaction: An application of the extended technology acceptance model. International Journal of Medical Informatics, 76, pp: 790-800.

[10] Kim, J. 2005. User acceptance of web-based subscription database. Dissertation of Doctor, Tallahassee Florida: Information Studies Department Florida State University.

[11] Ma, Q., \& Liu, L. 2004. The technology acceptance model: a metaanalysis of empirical findings. Journal of Organizational and End User Computing (JOEUC), 16, pp. 59-72.

[12] Moon, J., \& Kim, Y. 2001. Extending the TAM for a World-Wide-Web context. Information \& Management, 38, pp: 217-230.

[13] Park, S.Y. 2009. An Analysis of the Technology Acceptance Model in Understanding University Students' Behavioral Intention to Use eLearning. Educational Technology \& Society, Vol.12, No. 3, pp: 150162.

[14] Rosenberg, M. J. 2001. E-learning: Strategies for delivering knowledge in the digital age. New York: McGraw-Hill.

[15] Thong, J.Y.L., Wong, W., \& Tam, K.Y. 2004. Determinants of user acceptance of digital libraries: An Empirical Examination of Individual Differences and System Characteristics. Journal of Management Information Systems, 18(3).

[16] Wijaya, A. 2016. Analysis of Factors Affecting the Use of Google Classroom to Support Lectures. The 5th ICIBA 2016, International Conference on Information Technology and Engineering Application, pp: 61-68. 